\title{
Zbiór tłoków i stempli pieczętnych w zasobie Archiwum Państwowego w Poznaniu, red. P. Pokora, przy współ. M. Hlebionka, Poznań 2015, ss. 335
}

Sfragistyka jest jedną z nauk pomocniczych historii, która daje naukowcom duże możliwości w badaniu dziejów minionych. W przypadku ziem polskich pieczęci pojawiają się już w okresie średniowiecza i stanowią one wartościowy materiał naukowy aż do czasów współczesnych. W związku z tym, iż sfragistyka wciąż stanowi wartościowy element badań historycznych to rozprawa Zbiór ttoków i stempli pieczętnych w zasobie Archiwum Państwowego w Poznaniu musiała spotkać się dużym zainteresowaniem naukowców. Wskazane jest więc, aby opracowanie doczekało się recenzji, w ramach której można będzie ocenić jakość książki.

Przypomnijmy, że na 335 stronach omówiono w formie katalogowej 731 pieczęci zgromadzonych w Archiwum Państwowym w Poznaniu. W konstruowaniu opracowania oprócz redaktorów brało udział dziewięciu autorów związanych z różnymi ośrodkami naukowymi w Polsce, m.in. Częstochową, Poznaniem czy Toruniem. Dodatkowo przedmową rozprawę opatrzył dyrektor Archiwum Państwowego w Poznaniu Henryk Krystek (s. V-VII). Natomiast redaktorami rozprawy oraz autorami niektórych opisów zostali Piotr Pokora i Marcin Hlebionek. Obaj naukowcy są wybitnej rangi fachowcami zajmującymi się sfragistyką w prowadzonych przez siebie badaniach ${ }^{1}$.

\footnotetext{
1 Wśród najważniejszych prac wymienionych autorów można wymienić m.in. M. Hlebionek, Pieczęcie Piastów kujawskich, Inowrocław 2011; tenże, Katalog pieczęci przy dokumentach samoistnych w zasobie Archiwum Państwowego w Bydgoszczy, Warszawa 2012; Album rysunków pieczęci Kajetana Wincentego Kielisińskiego ze zbiorów Biblioteki Kórnickiej Polskiej Akademii Nauk, wyd. P. Pokora, Kórnik 2013. Obaj autorzy zajmowali się również innymi zagadnienia-
} 
Praca składa się ze wspomnianej już przedmowy, wstępu, 11 rozdziałów, gdzie zostały omówione pieczęcie, indeksu i bibliografii. Szczególnie przydatnym elementem rozprawy jest indeks (s. 321-324), który przy tak rozległej pracy ułatwia wyszukiwanie wybranych informacji. Dodać należy również, że opracowanie zostało tak przygotowane, że przynajmniej w części opisowej może swobodnie korzystać z niego anglojęzyczny czytelnik. Jest to szczególnie ważne w obliczu upowszechniania polskich wyników badań naukowych na arenie międzynarodowej. Redaktorzy zbioru podjęli więc spory wysiłek, aby opracowanie dotarło również do zagranicznego czytelnika.

Kluczowa część pracy składa się z części katalogowej podzielonej na 11 rozdziałów. Autorzy w ramach nich omawiają kolejno pieczęcie: królewskie, duchowieństwa, urzędowe imienne, instytucji kościelnych, wiejskie, sądowe, ziemskie, urzędów i instytucji, miejskie cechowe, różne oraz kolekcję Artura Breyera. Każdorazowo autorzy krótko prezentują zbiór, aby następnie przejść do katalogowego omówienia danych pieczęci. W tym przypadku oprócz opisu znajdujemy również bogaty materiał fotograficzny ilustrujący matrycę typariusza lub stempla. Pozwala on lepiej zilustrować podejmowaną przez autorów opracowania problematykę. Należy podkreślić imponujący wkład pracy autorów w wykonanie katalogu i docenić rozmach zrealizowanego zadania.

Omawiana rozprawa jest w zasadzie katalogiem źródeł sfragistycznych, w którym kompleksowo zaprezentowano zbiór Archiwum Państwowego w Poznaniu. $\mathrm{Z}$ punktu widzenia naukowca praca stanowi kompendium wiedzy, które może być cennym uzupełnieniem wiadomości z zakresu historii miast, duchowieństwa czy cechów rzemieślniczych. Szczególnie interesujące z punktu widzenia regionalistów wydawać się muszą pieczęcie cechowe czy miejskie z takich ośrodków, jak np.: Leszno, Mogilno, Oborniki, Pleszew czy Trzemeszno. Jakość rozprawy oraz sposób jej wydania w oparciu o liczny materiał ilustracyjny może zachęcać również osoby nieinteresujące się na co dzień historią do sięgnięcia po omawianą książkę.

Zbiór tłoków i stempli pieczętnych w zasobie Archiwum Państwowego w Poznaniu jest pracą, która z pewnością wpisze się w kanon opracowań sfragistycznych

mi, zob. Dokumenty strony polsko-litewskiej pokoju metneńskiego z 1422 roku, wyd. P. Pokora, P. Nowak, Poznań 2004; M. Hlebionek, Studia z dziejów Trzcianki i ziemi trzcianieckiej, Trzcianka 2005; tenże, Kasztelania czarnkowska, Czarnków 2006; tenże, Bolesław Pobożny $i$ Wielkopolska jego czasów, Kraków 2010; tenże, Kasztelania wieleńska. Studia z dziejów Wielenia i ziemi wieleńskiej, Poznań 2010. 
charakteryzujących się wysokim poziomem merytorycznym i edytorskim. Poruszane zagadnienia, rozmach badawczy i świadomość metodologiczna redaktorów zbioru sprawiają, że otrzymaliśmy bardzo rzetelne opracowanie, które na długo powinno wpisać się w dzieje studiów sfragistycznych.

dr Marcin Danielewski,

Instytut Historii, Wydział Historyczny,

Uniwersytet im. Adama Mickiewicza,

ul. Umultowska 89d, 61-614 Poznań,

m_danielewski@tlen.pl 